\title{
Fair Value Accounting and Corporate Reporting in Nigeria: A Logistics Regression Approach
}

\author{
A. E. Adegboyegun ${ }^{1}$, E. Ben-Caleb ${ }^{1}$, A. O. Ademola ${ }^{1}$, J. U. Madugba ${ }^{1} \&$ D. F. Eluyela ${ }^{1}$ \\ ${ }^{1}$ Department of Accounting \& Finance, Landmark University, Omu-Aran, Kwara State, Nigeria \\ Correspondence: A. E. Adegboyegun, Department of Accounting \& Finance, Landmark University, Omu-Aran, \\ Kwara State, Nigeria. Tel: 234-806-723-8841.
}

Received: August 26, 2019

Accepted: November 29, 2019

Online Published: March 17, 2020

doi:10.5430/ijfr.v11n2p301

URL: https://doi.org/10.5430/ijfr.v11n2p301

\begin{abstract}
This study examined the impact of fair value accounting on corporate reporting in Nigeria. The primary data used were gathered through a well-structured questionnaire, designed and administered to 120 respondents, who are made up of accountants, auditors, bankers, financial experts and practitioners in Lagos State, Nigeria. We adopted the logistic regression approach in analyzing the research questions. We found that fair value accounting has impact on corporate reporting. The Cox and Snell's R-Square revealed that $67.1 \%$ of the variation in the corporate reporting was explained by the logistic model. We further found a moderate strong relationship between the fair value accounting and corporate reporting. Based on this finding, the study concluded that the used of fair value helped in predicting the earnings and assessment of the amounts, timing and uncertainty of future cash flows in corporate reporting which dependent on its reliability. However, institutional factors played an essential role in enhancing the reliability of discretionary fair value estimates which in return increased the informativeness of accounting information in corporate reporting.
\end{abstract}

Keywords: corporate reporting, estimates, fair value accounting, logistic regression

\section{Introduction}

Fair value accounting is a financial reporting approach in which companies are required or permitted to measure and report the existing financial instruments based on certain estimated prices of an asset and liability received, thus, implies the estimated prices received for selling the assets or pay for relieved liabilities (Ryan, 2008). Fair value simply implies price obtained or amounts paid for selling an asset or for transferring of liability between market participants in an orderly transaction at a particular date. Obazee (2009) identified some basic issues affecting the fair value accounting implementation in Nigeria. These includes: traded government and corporate bonds; model valuation development expert; complex valuations for fair value of Foreign Exchange Contracts measurement; Cross Currency swaps of Interest Rate and the regulators will that allow measurement of fair value for financial instruments of entities. This suggested that the regulatory accounting standards body should provide enabling environment to determine inactive markets in other to ascertain forced or distressed transaction (Falaye et al, 2019).

According to Ryan (2008), it was noted under fair value accounting that firms reported losses due to decreases in asset fair value or increases in liability fair value and as such reduces firms reported net income. It must be noted that fair value is an entity estimated price expected to realize if an asset were sold or expected price to be paid for a relieve liability. Also, many financial instruments such as traded shares and securities are measured and reported at fair value. Landsman (2005) viewed and discovered that fair value report supports its reliability and relevancy for loans and other financial instrument at fair value. Barth and Landsman (1995) carried out study on the source of volatility in financial statements and the amount attributed for using fair values as the basis of measurement. Thus, the study identified conditional changes in economic and entity's activities that are reflected in the financial statements during the period. It was further discovered in measurement of accounting basis that fair value provides better economic volatility than any other based on historical measured.

Lefebvre, Simonova and Scarlat (2009) identified inactive market, shortage of skills, government influence in the markets, regulatory environment that is not strong, high cost, and lack of standard valuation and guiding rules as some of the vital issues associated with the use of fair value accounting in developing countries. According to Power (2010), it was argued that to engender the reliability of the accounting estimate, debate on fair value should not be 
taken for granted. It would be unhelpful to characterize what is at stake with subjective and objective language. However, it must be noted that without more dedication from the preparers, auditors, regulators, and users, changes in accounting principles will not be effective. It was observed that comparison between the principles of fair value and historical cost on the basis of accounting and reporting required complete and comprehensive analysis of technique and assumptions to be adopted in determining the values in the financial statements. Thus, require the redesigning of the current financial reporting model and education on the application of the new principles by the market participants (Okere et al, 2019).

Knott et al (2014) asserted that the practice of using fair value as a measuring element has been significantly enhanced. Also, the financial markets advancement and complex financial instruments development happened with the passage of time. There are numerous implications on balance sheet measurement, role, properties as well as income accounting as a result of cost and transaction-based model reduction and an increase in fair value-based model of financial reporting. This paradigm shifts in measurement occurred due to the alleged idea in relation to quality and relevant decision associated with the measure based on fair value as opposed to measure based on cost. Also, Bratten (2012) opined that the 2008 global financial crisis created a vital argument on fair value accounting in relation to regulators, researchers in accounting and banking professionals as well as other people. The fair value accounting concept critics faulted and amplified the crisis as the major causes of financial failure. To certain extent, this has helped in confirming a set of falling prices and increase in financial system total risk. The unreliability and volatility of fair value income is often subjected to managerial discretion especially when markets experiencing distressed. On the other hand, fair value method was arguably belief to produce the relevant timely measures of prices for assets as well as liabilities. According to Ball (2005), it was noted that fair value accounting seems to be obvious and fundamental to most economist due to the incorporation of more information into financial statements.

In contrary, Wallison (2008) opined that fair value accounting was the primary causes of an exceptional decline in the values of an asset; an extraordinary rise in instability among the financial institutions; and the most horrible economic crisis in the United States since the Great Depression. Also, Wallison (2009) believed that fair value accounting is extremely pro-cycling and should be neglected or at least significantly modified in order to ensure the stability of the entity rather than the earnings power presented in the financial statements. Chea (2011) and Okafor and Ogiedu (2012) reported that there is a fundamental inconsistency between fair value as a basis of measuring financial instruments and historical cost as a basis of measuring non-financial instruments. Standard-setters observed divergence and complicacies when a confine is drawn between financial statement items with diverse measuring methods. Thus, due to the dissimilarity and various views manifesting from the fair value method usage, this research sought to examine empirically the impact of fair value accounting on the effective corporate reporting in Nigeria.

\section{Literature Review}

Procházka (2011) emphasized that fair values involve a complete estimation of an asset value in terms of the amounts, time, and risk of the cash flows attributed to the assets in the future. As such it was believed that efficiency of the market would be improved upon if the information based on the decisions made were reported in the financial statements at a fair value. The fundamental of accounting measurement is important factors in the course of preparing financial statements, with a fair presentation of economic activity for an accounting entity. Essentials of financial statements are measured by diverse attributes, corresponding to the nature of an element and the purpose entity. The key factors to be considered in measuring assets, liabilities, equity and other elements were based on reliability and relevant.

American Bankers Association (2009) observed that the challenges associated with financial markets today can be linked to diverse factors. One of such factors is the fair value accounting. It was explained that fair value accounting is held for the purpose of asset trading. However, for loans, leases, and securities that are held to mature in the commercial banks, it was argued especially during crisis that fair value accounting was inappropriate and misleading when the markets are illiquid. However, when the reliability and relevance of fair value was considered according to Song, Thomas and Yi (2010) study, the relevance of fair values was revealed in explaining the share prices. The study further revealed important facts that acknowledged and disclosed fair value as a measure relevant to investors and reflected in the reliability of the share prices. Fair value measures with consistent description, incorporate all the fundamentals of financial instrument measurement, involve a high level of market discipline that was relevant and require for taking decision on the investment of the financial instruments within the basic financial statements. Laux and Leuz (2009) reported that the controversy surrounding the fair value assets were as a result of the uncertainty about the views on the rationale behind the fair value assets. It was argued that the debate on fair value asset was a 
trade-off between relevance and reliability been debated for over decades and had been dated back to a number of old accounting issues. Also, it must be noted that the recognition of the importance of accounting regulations in interaction with the other fundamentals of institutional structure should be done in order to avoid unintended consequences. Thus, stressed the need to shun every form of deviation from market prices appropriately to avoid litigation. It is observed that to recognize management flexibility in dealing with potential problems of fair value assets particularly in crisis period promotes manipulation. However, managers are encouraged to avoid impair loses by using a market value deviation allegedly depressed.

Pacter (2007) observed the views of fair value accounting by Nigeria auditors and it was revealed that fair value accounting is more useful than the historical cost as revealed by the prepared financial statements. It was further discovered that auditors experienced low level of fair value awareness, the challenges posed to auditor was more pronounced in fair value and as such, it was claimed to be inappropriate in Nigeria context. Lefebvre, Simonova and Scarlat (2009) stated that at a regular market price, fair value accounting involves revaluation of unsold assets and liabilities. This is usually applied to financial assets and liabilities. However, non-financial assets are also subject to fair value evaluation.

Nelson (1996) investigated the relevance of fair value in determining market capitalization. The study employed a sample of 279 banks selected between 1992 to 1993. The analysis done using descriptive analytic technique revealed that fair value measures are relevant in explaining market capitalization. However, loans, long-term deposits and debts recorded using fair value principle have no information content. Moreover, Barth and Clinch (1998) study carried out on fair value asset evaluation using sample composed of 350 Australian companies over the period from 1991 to 1995 . The result showed that fair value of intangible assets is relevant while that of tangible assets has no information content for all firms. Juettner-Nauroth (2003) carried out study to analyze the relationship between the share at market value and the fair value of derivatives determined according to IAS 39 in inactive market. The information gathered for the study were analyzed and the result indicated the irrelevancy of the fair value of derivative instruments when trading is done in an active market.

Christensen and Nikolaev (2012) examined whether fair value accounting for non-financial assets pass the market test in consideration with the alternative historical cost. The analysis of collected data on the study was done using descriptive analytic technique and the result revealed that fair value applied to buildings and equipment were less efficient for decision making when compared to historical cost. Investigation further revealed that financial reporting standards provided feature not offered by other standards in the corporate field to choose between historical cost and fair value for non-financial assets.

Raini et al. (2012) studied the advantages and challenges of the perception by examining its effect on financial reporting roles and determined appropriate alternatives technique for forecasting in Fiji. It was discovered from the study that both the users and preparers of financial reports have appropriate knowledge of fair value accounting. Thus, markets that are active, independent values and cost involve in referrals as identified measuring methods. A relevant disclosure and information was identified as benefit. The study also identified costs involve in training and hiring of professionals, the use of subjective judgment and prediction as the challenges of fair value accounting in the long run. Pranil et al (2011) examined the application of fair value accounting in Fiji financial sector. Fair value information based on the perspectives of preparers and users were put into consideration using selected sample of four banks and credit institutions and two investment companies. A well-structured questionnaire was designed to collect data which were analyzed using descriptive analytic technique. The results obtained shown that the users perceive fair value accounting information was useful for the purpose of decision making. However, the impact of Fair value accounting on effective corporate reporting in Nigeria was examined in this study using logistic regression approach.

\section{Methodology}

The study adopted survey and explanatory research design (Akintimehin et al, 2019). Primary data used were collected through administration of a well-structured questionnaire in Lagos. The data were collected from accountants, auditors, bankers, financial experts and practitioners. Thus, a sample size of 100 respondents returned their completed questionnaire out of the 120 administered questionnaires using a simple random sampling technique. Frequency and percentages, tables, Regression Analysis and Goodman and Kruskal's gamma statistics were used to analyze the data (Oladipo et al, 2019a; Eluyela et al; 2018a; 2018b; Ademola, Adegoke \& Adegboyegun, 2019). 


\subsection{Measurement of Variables}

The logistic regression analysis will be used to understand the impact of fair value accounting on corporate reporting in Nigeria (Eluyela et al, 2019a; 2019b). The general model is:

$$
y=f(x)
$$

The implicit form of our empirical model adapted from the work of (Halid \& Akinnitire, 2013) is:

$$
C P R=\beta_{0} F A V^{\beta_{1}}
$$

The explicit form of the model after including panel data model properties is presented in equ (3):

$$
C P R_{i t}=\beta_{0}+\beta_{1} F R V_{i t}+\beta_{2} R E A_{i t}+\beta_{3} R E L_{i t}+\beta_{4} C O M_{i t}+\mu_{i t}
$$

Where;

$C P R=$ corporate reporting,

$F R V=$ fair value measurement,

$R E A=$ reliability of financial information,

$R E L=$ relevance of financial information,

$C O M=$ comparability of financial information,

$\mu=$ error term

\subsection{Model Specification}

The logistic model previously used in health and business decision by (Ogunleye \& Fagbohun, 2009; Halid and Akinnitire, 2013; Oladipo et al, 2019b) was adopted with modification for this study and stated as follows:

The dependent variable $Y=1$ indicating that fair value effectively impacted corporate reporting and $Y=2$ if otherwise, then

$$
\begin{gathered}
P_{i}=\mathrm{E}\left(Y=1 \mid X_{i}\right)=\frac{1}{1+e^{-\left(a_{1}+a_{2 i} X_{i}\right)}} \\
P_{i}=\frac{e^{\beta_{i}}}{1+e^{\beta_{i}}}
\end{gathered}
$$

Equation 5 was called the logistic cumulative distribution function and $P_{i}$ was ranged from 0 to 1 , called the probability that fair value accounting method effectively impacted corporate reporting, $\beta_{i}$ ranges from $-\infty$ to $+\infty$. $P_{i}$ was non-linearly related to $\beta_{i}$ and $a_{2 i}{ }^{\prime} s$ were the model coefficients. Since $P_{i}$ was the probability that fair value accounting impact on corporate reporting, then

$$
1-P_{i}=\frac{1}{1+e^{\beta_{i}}}
$$

Equation 6 was called the probability that fair value accounting does not have impact on corporate reporting. Then, Equation 7 was called the odds ratio in favour of the probability that fair value accounting has impact on corporate reporting to the probability that it was otherwise.

$$
\frac{P_{i}}{1-P_{i}}=e^{\beta_{i}}
$$

Taking the natural logarithm of equation 7 given expression in 8

$$
\begin{gathered}
\hat{\mathrm{L}}_{i}=\ln \left(\frac{P_{i}}{1-P_{i}}\right) \\
\hat{\mathrm{L}}_{i}=\beta_{i}=a_{1}+a_{2 i} X_{i}+\mu_{i}
\end{gathered}
$$


Equation 8 was called logistic model and its transformation in linear form was expressed in equation 9. $\dot{L}_{i}$ was called the logit, $X_{i}$ were the sex (SEX), education level (EDL), professional certification (PROF), reliability (RFVA), relevant (REFV) and comparability (COFV) of fair value accounting. However, $a_{1}$ was the constant term for the logistic regression model, $a_{2 i}$ were the parameters of the logistic regression model to be estimated and $\mu_{i}$ was the error term.

\section{Result and Discussion}

The data collected for this study was analyzed using binary logistic regression technique because it gives efficient, consistent unbiased estimate of the model parameters. The logistic regression technique allows the estimation of probability that fair value accounting enhanced or not corporate reporting by predicting a binary dependent outcome from a set of independent variables such as were the sex (SEX), education level (EDL), professional certification (PROF), corporate reporting (CORP), reliability (RFVA), relevant (REFV) and comparability (COFV) of fair value accounting. The evaluation and diagnostic techniques of the model were also done using classification table, Cox \& Snell R Square, Nagelkerke R Square, Hosmer and Lemeshow goodness-of-fit test, probability test and old ratio. These were presented below:

Table 1. Classification table

\begin{tabular}{|c|c|c|c|c|c|}
\hline & \multicolumn{2}{|c|}{ Observed } & \multicolumn{3}{|c|}{ Predicted } \\
\hline & & & \multicolumn{2}{|l|}{$\overline{\text { FVA }}$} & \multirow{2}{*}{ Percentage Correct } \\
\hline & & & Impacted & Not impacted & \\
\hline \multirow[t]{3}{*}{ Step 0} & \multirow[t]{2}{*}{ FVA } & Impacted & 0 & 46 & .0 \\
\hline & & Not impacted & 0 & 54 & 100.0 \\
\hline & \multicolumn{3}{|c|}{ Overall Percentage } & & 58.4 \\
\hline
\end{tabular}

Source: Researchers' Computation, 2019

Table 2. Variables in the equation

\begin{tabular}{llllllll}
\hline & & B & S.E. & Wald & Df & Sig. & $\operatorname{Exp(B)}$ \\
\hline Step 0 & Constant & .274 & .213 & .754 & 1 & .615 & 1.060 \\
\hline
\end{tabular}

Source: Researchers' Computation, 2019

Tables 1 and 2 present the results when the constant term was included and all the predictor variables such as sex, education level, professional qualification, reliability of fair value accounting, relevance of fair value accounting and comparability of fair value accounting were excluded from the model. The model without and with all the aforementioned predictors are compared to determine whether the latter model is more appropriate. The table 1 suggested that model without the predictors would be 58.4 percent of the time correct that fair value accounting have impact on corporate reporting as revealed by the classification table. The probability value of the Wald statistic of 0.615 which is greater than $0.05(\mathrm{P}>0.05)$ revealed that fair value accounting has significance impact on the corporate reporting.

The Exp(B) column in Table 2 presents the extent to which a percent improvement in the adoption of fair value accounting would impact or influence the odds ratio. Thus, EXP(B) value 1.060 as revealed in this study implies that an improvement on the adoption of fair value accounting, the odds ratio would be 1.06 percent higher and hence fair value accounting are more likely to impact better corporate reporting by 1.06 percent.

Table 3. Variables not in the equation

\begin{tabular}{|c|c|c|c|c|c|}
\hline & & & Score & Df & Sig. \\
\hline Step 0 & Variables & SEX & .031 & 1 & .891 \\
\hline
\end{tabular}




\begin{tabular}{llll} 
EDL & .374 & 1 & .534 \\
\hline PROF & 3.272 & 1 & .121 \\
\hline RFVA & 21.132 & 1 & .000 \\
\hline REFV & 8.635 & 1 & .012 \\
\hline COFV & 8.635 & 1 & .012
\end{tabular}

Source: Researchers' Computation, 2019

The variables not in the equation table presented in Table 3 revealed that sex, educational level and professional certification with probability value $0.891,0.534$ and $0.121>0.05$ does not significant impact on the corporate reporting. However, it was discovered that reliability relevant and comparability of fair value accounting with associated probability value of $0.000,0.012$ and $0.012<0.05$ were significant and therefore have significance impact on corporate reporting. The significance of the fair value accounting measures further revealed a better improvement of corporate reporting. Thus, implies the important of fair value accounting in enhancing corporate reporting.

Table 4. Model summary

\begin{tabular}{llll}
\hline Step & $\mathbf{- 2}$ Log likelihood & Cox \& Snell R Square & Nagelkerke R Square \\
\hline $\mathbf{2}$ & $69.397^{\mathrm{a}}$ & .671 & .719 \\
\hline
\end{tabular}

Source: Researchers' Computation, 2019

Model Summary presented in Table 4, provides the approximate coefficient of determination $\left(\mathrm{R}^{2}\right)$. Cox and Snell's R-Square implies multiple R-Square based on 'likelihood' and thus revealed that 67.1 percent of variation in the corporate reporting can be explained by the logistic model. The modified Nagelkerke's $\mathrm{R}^{2}$ was a reliable measure of the relationship. It was discovered in this study that Nagelkerke's $\mathrm{R}^{2}$ was 0.719 which showed a moderate strong relationship between fair value accounting and the corporate reporting.

Table 5. Hosmer and Lemeshow test

\begin{tabular}{llll}
\hline Step & Chi-square & Df & Sig. \\
\hline $\mathbf{2}$ & 9.451 & 3 & .065 \\
\hline
\end{tabular}

Source: Researchers' Computation, 2019

An alternative to model chi square was the Hosmer and Lemeshow goodness-of-fit test presented in Table 5. The Hosmer and Lemeshowtest statistic of $0.065>0.05$ revealed that the observed and model-predicted values are the same. Thus, implies that the model's estimates fit the data at 5 percent level of significance. The insignificance of the result indicated that the model prediction does not differ from the observed. Hence, the assumed sampling adequacy that establish that fitted logistic model was good, adequate and reliable for examining the impact of fair value accounting on corporate reporting.

Table 6. Classification table

\begin{tabular}{|c|c|c|c|c|c|}
\hline & \multirow{3}{*}{\multicolumn{2}{|c|}{ Observed }} & \multicolumn{3}{|l|}{ Predicted } \\
\hline & & & \multicolumn{2}{|l|}{ FVA } & \multirow{2}{*}{ Percentage Correct } \\
\hline & & & Impacted & Not impacted & \\
\hline \multirow[t]{3}{*}{ Step 2} & \multirow[t]{2}{*}{ FVA } & Impacted & 34 & 12 & 73.9 \\
\hline & & Not impacted & 10 & 44 & 81.5 \\
\hline & \multicolumn{2}{|c|}{ Overall Percentage } & & & 77.7 \\
\hline
\end{tabular}

Source: Researchers' Computation, 2019 
Classification Table presented in Table 6 was used rather than goodness-of-fit statistic to show the proportion of cases that were managed to classify correctly. The classification Table revealed the number of cases correctly predicted that the observed values of the corporate reporting were influenced by the impact of fair value accounting. In this study, 73.9 percent were classified correctly for the fair value accounting impact on corporate reporting and 81.5 percent for the fair value accounting do not have impact on corporate reporting. Overall 77.7 percent were classified correctly. This revealed a considerable improvement over the 58.4 percent correct classification without the inclusion of significant independent variables such as reliability, relevance and comparability of fair value accounting in the model. Thus, fair value accounting measures significantly an improvement in corporate reporting.

Table 7. Variables in the equation

\begin{tabular}{lllllllll}
\hline & & B & S.E. & Wald & Df & Sig. & $\operatorname{Exp}(\mathbf{B})$ \\
\hline tep 2 & RFVA & 160.619 & 26872.143 & .000 & 1 & .979 & $1.248 E+014$ \\
\cline { 2 - 8 } & REFV & -52.330 & 11767.448 & .000 & 1 & .979 & .000 \\
\cline { 2 - 8 } & Constant & -34.983 & 14105.956 & .000 & 1 & .979 & .000 \\
\hline
\end{tabular}

Source: Researchers' Computation, 2019

Variables in the Equation presented in the Table 7 had several important as the impact of the independent variables such as reliability and relevance of fair value included in the model. The Wald statistic and associated probabilities provided the impact and the significance of each of the independent variable in the equation. The Wald statistic has a chi-square distribution that can be determined by the significance of the Wald statistic. Thus, if $\mathrm{P}<0.05$ the null hypothesis is rejected which showed insignificance impact of the variable. Thus, in this study, it was discovered that the probability value of the reliability and relevance fair value accounting which are 0.979 and 0.979 respectively were greater than 0.05 that is, $\mathrm{P}>0.05$. Therefore, it implies that reliability and relevance of fair value accounting have significant impact on the corporate reporting.

The $\operatorname{Exp}(\mathrm{B})$ column in Table 7 presents the extent to which improving the corresponding measure by one unit influences the odds ratio. Interpreting $\operatorname{EXP}(B)$ in terms of the change in odds. Hence, the $\operatorname{EXP}(B)$ value associated with reliability of fair value accounting is $1.248 \mathrm{E}+014$. Therefore, when fair value improved by one percent the odds ratio is increased by $1.248 \mathrm{E}+014$ times thus the influence on corporate reporting. The ' $\mathrm{B}$ ' values are the logistic coefficients that can be used to create a predictive equation given as:

$$
\mathrm{P}=\frac{e^{\{(160.619 * R F V A)-(52.330 * R E F V)-34.983\}}}{1+e^{\{(160.619 * R F V A)-(52.330 * R E F V)-34.983\}}}
$$

$\mathrm{P}=1$, thus implies that fair value accounting has significant impact on corporate reporting. The ratio of odds ratios of reliability and relevant of the fair value accounting was the ratio of relative impact on the corporate reporting. In this study, reliability of fair value accounting was $1.248 \mathrm{E}+014$ times as important as relevance and comparability of fair value accounting in determining the corporate reporting.

\section{Conclusion and Recommendation}

A thorough examination of the impact of fair value accounting on corporate reporting revealed that it enhanced corporate reporting as shown by the classification table. The study established that fair value accounting has significant impact on corporate reporting as revealed by the Wald statistic and associated probabilities. Also, in this study, it was correctly classified 73.9 percent of the time that fair value accounting has impact on corporate reporting and in overall, it was 77.7 percent. This was considered to be better improvement over 58.4 percent correct classifications without the inclusion of reliability, relevant and comparability of fair value accounting in the model. Thus, according to Song, Thomas and Yi (2010), it was revealed that fair values are relevant in determining the share prices recorded in corporate reporting. The study further revealed substantial evidence on the relevant of fair value to an investor and this is reliable enough to influence the share prices recorded in corporate reporting. Also, it was discovered that the probability value of the reliability and relevant of fair value which are 0.979 and 0.979 respectively were greater than 0.05 that is, $\mathrm{P}>0.05$. Therefore, implies that reliable and relevant fair value accounting contributed significantly to the corporate reporting. This affirmed the position of Landsman (2005) that 
established relevant and reliable fair value accounting in corporate reporting of loans and other financial instruments. Reliability of the fair value accounting was 1.2484+014 times more important than the relevant and comparability of the fair value in determining the corporate reporting. The $\operatorname{Exp}(B)$ value 1.060 as revealed in this study implies that an improvement in fair value accounting are more likely to enhance corporate reporting by 1.19 percent for the model with only constant. This according to Pacter (2007), it was emphasized that corporate reporting under fair value accounting basis is more reliable and relevant than the historical cost basis. Therefore, findings from this study have important implications for standard setters and contribute to the debate on the use of fair value accounting.

The results support claims by the FASB and the IASB that fair value accounting meets the objectives of corporate financial reporting by providing decision-useful information due to the significance of the fair value measurement such as reliability, relevance and comparability under consideration. That is, the use of fair value helps in predicting the earnings and assessment of the amounts, timing and uncertainty of future cash flows in corporate reporting. However, it was revealed that the predictive power of fair values dependent on its reliability. Moreover, based on evidence, institutional factors play an essential role in enhancing the reliability of discretionary fair value estimates which in return increases the informativeness of accounting information. This also helps the reduction of corporate collapse and impoverishment of investors that can influence corporate growth and achievement.

\section{References}

Ademola, A. O., Adegoke, K. A., \& Adegboyegun, A. E. (2019). Nexus Between Informal Financial Institutions (IFIs) and Performance of Women Entrepreneurs in Nigeria. Saudi Journal of Economics and Finance. Retrieved from https://scholarsmepub.com/sjef-39/

Akintimehin, O. O., Eniola, A. A., Alabi, O. J., Eluyela, D. F., Okere, W., \& Ozordi, E. (2019). Social Capital and its Effect on Business Performance in the Nigeria Informal Sector. Heliyon, 5. https://doi.org/10.1016/j.heliyon.2019.e02024

American Bankers Association. (2009). Fair Value and Mark to Market Ac-counting. Retrieved from http://www.aba.com/Issues/Issues_FairValue.htm

Ball, R. (2005). International Financial Reporting Standards (IFRS) Pros and Cons for Investors. PP Leake Lecture delivered on 8 September 2005 at the Institute of Chartered Accountants in England and Wales.

Barth, M. E., \& Clinch, G. (1998). Revalued financial, tangible, and intangible assets: associations with share prices and non-market-based value estimates. Journal of Accounting Research, 36, 199-233. http://doi.org/10.2307/2491314

Barth, M., \& Landsman, W. (1995). Fundamental issues related to using fair value accounting for financial reporting. Accounting Horizons, 97-107.

Ben-Caleb, E., Faboyede, S., Olusanmi, O., Oyewo, B., Fakile, S., Adegboyegun, A. E., \& Ademola, A. (2019). Financial Literacy: A Panacea to Poverty Reduction in Nigeria. International Journal of Civil Engineering and Technology (IJCIET), $\quad$ 10(2), 301-309. $\quad$ Retrieved from http://www.iaeme.com/ijciet/issues.asp?JType=IJCIET\&VType=10\&IType $=2$

Bratten, B., Causholli, M., \& Khan. U. (2014). Usefulness of fair values in predicting future cash flows and earnings. Working paper, University of Kentucky.

Chea, A. C. (2011). Fair Value Accounting: Its Impacts on Financial Reporting and How It Can Be Enhanced to Provide More Clarity and Reliability of Information for User of Financial Statements. International Journal of Business and Social Science, 2(20), 12-19

Christensen, H. B., \& Nikolaev, V. (2012). Does fair value accounting for non-financial assets pass the market test?. The University of Chicago Booth School of Business. https://doi.org/10.2139/ssrn.1269515

Eluyela, D. F., Adetula, D. T., Oladipo, O., Nwanji, T. I., Adegbola, O., Ajayi, A., \& Falaye, A. (2019b). Pre and Post Adoption of IFRS Based Financial listed Small and Medium Scale Enterprises in Nigeria. International Journal of Civil Engineering and Technology, 10(1), 1097-1108.

Eluyela, D. F., Akintimehin, O. O., Okere, W., Ozordi, E., Osuma, G. O., Ilogho, S. O., \& Oladipo, O. A. (2018a). Datasets for Board Meeting Frequency and Financial Performance of Nigerian Deposit Money Banks. Data in Brief. https://doi.org/10.1016/j.dib.2018.06.044 
Eluyela, D. F., Akintimehin, O. O., Okere, W., Ozordi, E., Osuma, G. O., Ilogho, S. O., \& Oladipo, O. A. (2018b). Board Meeting Frequency and Firm Performance: Examining the Nexus in Nigerian Deposit Money Banks. Heliyon, 4, 850. https://doi.org/10.1016/j.heliyon.2018.e00850

Eluyela, D. F., Adetula, D. T., Obasaju, O. B., Ozordi, E., Akintimehin, O., \& Popoola, O. (2019a). Foreign Directors, Indigenous Directors and Dividend Payout Structure in Nigerian Deposit Money Banks. Banks and Bank System, 14(2), 1-14. https://doi.org/10.21511/bbs.14(2).2019.16

Juettner-Nauroth, B. (2003). Problems Associated with the Value-Relevance of Financial Derivatives according to IAS 39. SSE/EFI Working Paper Series in Business Administration No 2.

Knott, S., Richardson, P., Rismanchi, K., \& Sen, K. (2014). Understanding the fair value of banks' loans. Bank of England Financial Stability Paper, (31), 2-31. https://doi.org/10.2139/ssrn.2545783

Landsman, W. (2005, September). Fair Value accounting for financial Instruments: Some implications for bank Regulation. https://doi.org/10.2139/ssrn.947569

Laux, C., \& Leuz, C. (2009). The Crisis of Fair Value Accounting, Making Sense of the Recent Debate. Accounting Organizations and Society, 34(6/7), 826-834. https://doi.org/10.1016/j.aos.2009.04.003

Lefebvre, R., Simonova, E., \& Scarlat, M. (2009). Fair Value Accounting: The Road to be Most Travelled, Ontario. Certified General Accountants Association of Ontario.

Nelson, K. K. (1996). Fair Value Accounting for Commercial Banks: An Empirical Analysis of SFAS No. 107. Accounting Review, 161-182.

Obazee. (2009). Practical Implementation issues of International Financial Reporting Standard in Nigeria-Fair Value Measurement as a Challenging Matter. Nigeria Accounting Standard Board Nnamdi Azikiwe University, Awka.

Okafor, C., \& Ogiedu, K. O. (2012). Perceptions of Fair Value Accounting: Evidence from Nigeria. JORIND, 10(3), 417-432.

Okere, W., Eluyela, D. F., Lawal, A. I., Ibidunni, O., Eseyin, O., Popoola, O., \& Awe, T. (2019). Foreign Expatriates on Board and Financial Performance: A Study of Listed Deposit Money Banks in Nigeria. The Journal of Social Science Research, 5(2), 418-423. https://doi.org/10.32861/jssr.52.418.423

Oladipo, O. A., Iyoha, O. F., Fakile, A. S., Asaleye, A. J., \& Eluyela, D. F. (2019a). Do Government Taxes have Implication on Manufacturing Sector? Evidence from Nigeria. Journal of Management Information and Decision Sciences, 22(3), 181-190.

Oladipo, O. A., Iyoha, O. F., Fakile, A. S., Asaleye, A. J., \& Eluyela, D. F. (2019b). Tax Revenue and Agricultural Performance: Evidence from Nigeria, Problems and Perspectives in Management, 17(3), 342-349. http://doi.org/10.21511/ppm.17(3).2019.27

Pacter, P. (2007). Fair value under IFRS: Issues for DevelopingCcountries and SMEs, in the Routledge Companion to Fair Value and Financial Reporting (pp. 350-369). Walton, P, London: Routledge. https://doi.org/10.4324/NOE0415423564.ch24

Power, M. (2010). Fair Value Accounting, Financial Economics and the Transformation of Reliability. Accounting and Business Research, 40, 197-211. https://doi.org/10.1080/00014788.2010.9663394

Pranil, P., Dharmendra, N., Shiro, D., \& Jai, C. (2011). Fair Value Accounting in the Finance Sector: A Fiji Perspective. International Review of Business Research Papers, 7(1). Retrieved from http://irbrp.com/previous_issue/

Procházka, D. (2011). The Role of Fair Value Measurement in the Recent Financial Crunch. Prague Economic Papers, 1, 71-88. https://doi.org/10.18267/j.pep.388

Rajni, D., Joycelyn, D., Rashika, K., \& Charlotte, T. (2012). Accountant and User Perceptions of Fair Value Accounting: Evidence from Fiji. Global Journal of Business Research, 6(3). Retrieved from http://papers.ssrn.com/sol3/papers.cfm?abstract_id=1957299

Ryan, S. G. (2008). Fair Value Accounting: Understanding the Issues Raised by Credit Crunch. Financial Markets Institutions and Instruments, 18(2), 163-164. https://doi.org/10.1111/j.1468-0416.2009.00147_14.x 
Ryan, S. G., Herz, R. H., Iannaconni, T. E., Maines, L. A., Paletu, K., Schrand, C. M., \& Vincent, L. (2002). Reporting Fair Value Interest and Value Changes on Financial Instruments. Accounting Horizons, 16, 259-268. https://doi.org/10.2308/acch.2002.16.3.259

Song, C. J., Thomas, W. B., \& Yi, H. (2010). Value Relevance of FAS 157 Fair Value Hierarchy Information and the Impact on Corporate Governance Mechanisms. The Accounting Review. https://doi.org/10.2308/accr.2010.85.4.1375

Wallison, P. J. (2008). Fair Value Accounting: A Critique. American Enterprise Institute for Public Policy Research. Retrieved from http://www.aei.org/do-cLib/20080728_23336JulyFSOg.pdf

Wallison, P. J. (2009, March). Fixing Fair Value Accounting. Paris, OECD Accrual Accounting Symposium. https://doi.org/10.1787/budget-9-5ks72wvj5lmw 